\title{
Cultured pancreatic ductal cells undergo cell cycle re-distribution and $\beta$-cell-like differentiation in response to glucagon-like peptide-1
}

\author{
A Bulotta ${ }^{1,2}$, H Hui $^{1}$, E Anastasi ${ }^{2}$, C Bertolotto ${ }^{1,3}$, L G Boros ${ }^{4}$, U Di Mario ${ }^{2}$ and \\ R Perfetti ${ }^{1,3}$ \\ ${ }^{1}$ Cedars-Sinai Medical Center, Los Angeles, California, USA \\ 2University La Sapienza, Rome, Italy \\ ${ }^{3}$ University of California, Los Angeles, California, USA \\ ${ }^{4}$ Harbor-UCLA Research and Education Institute, Torrance, California, USA \\ (Requests for offprints should be addressed to R Perfetti, Division of Endocrinology and Metabolism, Cedars-Sinai Medical Center, 8723 Alden Drive, \\ SSB 290, Los Angeles, California 90048, USA; Email: perfettir@cshs.org)
}

\begin{abstract}
The intestinal hormone glucagon-like peptide-1 (GLP-1) has been shown to promote an increase in pancreatic $\beta$-cell mass via proliferation of islet cells and differentiation of non-insulin-secreting cells. In this study, we have characterized some of the events that lead to the differentiation of pancreatic ductal cells in response to treatment with human GLP-1.

Rat pancreatic ductal (ARIP) cells were cultured in the presence of GLP-1 and analyzed for cell counting, cell cycle distribution, expression of cyclin-dependent-kinase (Cdk) inhibitors, transcription of $\beta$-cell-specific genes, loss of ductal-like phenotype and acquisition of $\beta$-cell-like gene expression profile.

Exposure of ARIP cells to $10 \mathrm{nM}$ GLP-1 induced a significant reduction in the cell replication rate and a significant decrease in the percentage of cells in $S$ phase of the cell cycle. This was associated with an increase in the number of cells in G0-G1 phase and a reduction of cells in G2-M phase. Western blot analysis for the Cdk inhibitors, kinase inhibitor protein 1 (p27 $\left.{ }^{\text {Kip } 1}\right)$ and Cdk-interacting protein 1 (p21 $\left.{ }^{\mathrm{Cip} 1}\right)$, demonstrated a significant increase in p27 $7^{\mathrm{Kip} 1}$ and $\mathrm{p} 21^{\mathrm{Cip} 1}$ levels within the first $24 \mathrm{~h}$ from the beginning of GLP-1 treatment. As cells slowed down their proliferation rate, GLP-1 also induced a time-dependent expression of various $\beta$-cell-specific mRNAs. The glucose transporter GLUT-2 was the first of those factors to be expressed ( $24 \mathrm{~h}$ treatment), followed by insulin $(44 \mathrm{~h}$ ) and finally by the enzyme glucokinase $(56 \mathrm{~h})$. In addition, immunocytochemistry analysis showed that GLP-1 induced a time-dependent down-regulation of the ductal marker cytokeratin-20 (CK-20) and a time-dependent induction of insulin expression. Finally, GLP-1 promoted a glucose-dependent secretion of insulin, as demonstrated by HPLC and RIA analyses of the cell culture medium.

The present study has demonstrated that GLP-1 induces a cell cycle re-distribution with a decrease in cell proliferation rate prior to promoting the differentiation of cells towards an endocrine-like phenotype.
\end{abstract}

Journal of Molecular Endocrinology (2002) 29, 347-360

\section{Introduction}

Growth and differentiation of islet $\beta$-cells is not limited to the embryological state (Hellestrom et al. 1996, Bonner-Weir 2000a). A constant remodeling of size and function of the islets of Langerhans occurs during the entire life of individuals and is likely to play an essential role in the prevention of diabetes (Bonner-Weir 2001). The mass of $\beta$-cells is dynamically regulated to maintain euglycemia and its expansion has been proposed to be a compensatory mechanism for glucose homeostasis (BonnerWeir 1994). An increase in the overall islet mass has been shown in animals subjected to prolonged glucose infusion (Bonner-Weir et al. 1988), as well as in animal models of insulin resistance (Pick et al. 1998, Finegood et al. 2001) or in human subjects with obesity (Klöppel et al. 1985), and finally during pregnancy (Sorenson \& Brelje 1997). Failure to increase $\beta$-cell mass to compensate for an increased 
demand for insulin secretion leads inevitably to the onset of diabetes. The identification of cells capable of undergoing differentiation into insulin-producing cells, as well as the characterization of stimuli capable of promoting the acquisition of such a phenotype, may provide important insights in the designing of novel therapeutic agents capable of enhancing the proliferation and/or differentiation of $\beta$-cells so as to restore normal glycemia in subjects with diabetes.

It has been proposed that in adulthood two independent pathways are utilized for the proliferation of pancreatic endocrine cells: with the first one, new endocrine cells arise from the division and differentiation of cells within the islets; while with the second pathway newly formed islet cells originate from precursor cells located in the pancreatic ductal epithelium (Brockenbrough et al. 1988, Bonner-Weir et al. 1993, Gu \& Sarvetnick 1993, Wang et al. 1995, Fernandes et al. 1997, Waguri et al. 1997, Anastasi et al. 1999, Perfetti et al. 2000, Hui et al. 2001 ). In adult animals, the onset of hyperglycemia that follows subtotal pancreatectomy (Sharma et al. 1999) or treatment with the toxic agent streptozotocin (Wang et al. 1996) are characterized not only by a reduction of the pre-existing islet mass, but also by a compensatory attempt to replace the normal population of insulinsecreting cells. New $\beta$-cells are formed from existing islets and from ductal epithelial cells (Bonner-Weir et al. 1993). The latter source has greater intrinsic biological relevance. Indeed, the possibility of differentiating insulin-secreting cells from non-endocrine cells supports the hypothesis that the biological source (pancreatic ductal epithelium) for this compensatory mechanism may be present even in the setting of a generalized destruction of the entire population of islet $\beta$-cells. This is strongly supported by recent studies demonstrating that primary cultures of epithelial ductal cells (from human and mouse pancreas) are susceptible to undergo differentiation into endocrine cells (Bonner-Weir et al. 2000b, Ramiya et al. 2000).

It is likely that a co-ordinated activation of multiple differentiation factors, in a fashion similar to the sequence of events occurring during fetal development, may be required for the cellular growth of the endocrine pancreas in adults. The mechanism(s) for the activation of such a complex regulatory network in adulthood is not known. We have previously demonstrated that treatment of glucose-intolerant aging Wistar rats with the incretine hormone glucagon-like peptide-1 (GLP-1) restored normal glucose tolerance and induced islet cell proliferation (Wang et al. 1997, Perfetti et al. 2000). Similarly, Xu et al. (1999) demonstrated that an analogue of GLP-1, termed exendin-4, was able to increase islet mass in adult animals previously subjected to subtotal pancreatectomy. These studies suggest that exogenously administered stimuli are able, in vivo, to increase the mass of insulin-secreting cells and ameliorate glucose tolerance by inducing neogenesis of islet cells. Our previous studies have indicated that, by culturing pancreatic ductal cells with GLP-1, we could induce their differentiation into insulin-producing and -secreting cells (Hui et al. 2001). To gain additional insight into the mechanism(s) by which GLP-1 produces differentiation of insulinproducing cells, in the present study we analyzed the effect of GLP-1 on cell cycle distribution and G1 phase cyclin-dependent kinase (Cdk) inhibitor expression, as well as on the loss of the ductal-like phenotype, leading finally to the acquisition of a $\beta$-cell-like gene expression profile.

\section{Materials and Methods}

\section{Cell culture}

Rat pancreatic ductal (ARIP) cells were cultured in F12 medium (Gibco-BRL, Gaithersburg, MD, USA) containing 10\% fetal bovine serum (FBS; Gibco-BRL), $50 \mu \mathrm{g} / \mathrm{ml}$ streptomycin and $100 \mu \mathrm{g} /$ $\mathrm{ml}$ penicillin at $37^{\circ} \mathrm{C}$ under a humidified condition of $95 \%$ air and $5 \% \mathrm{CO}_{2}$. Cultures used for cell cycle analysis and immunocytochemistry were grown to approximately $70 \%$ confluence in serum-containing medium and cells were deprived of serum for $6 \mathrm{~h}$ before the addition of GLP-1 (10 nM; Bachem, Torrance, CA, USA).

To determine the effect of GLP-1 on p27 or kinase inhibitor protein $1\left(\mathrm{p} 27^{\mathrm{Kip} 1}\right)$ and $\mathrm{p} 21$ or Cdk-interacting protein 1 (p21 $\left.{ }^{\mathrm{Cip} 1}\right)$ expression, ARIP cells were cultured to $50 \%$ confluence $\left(\sim 2 \times 10^{6}\right.$ cells $)$ in serum-containing medium and then serum starved for $24 \mathrm{~h}$ in serum-free F12 (time $0)$. The cells were re-exposed to serum-containing medium for $24 \mathrm{~h}$ before being cultured for increasing lengths of time with or without GLP-1 $(10 \mathrm{nM})$. The glucose concentration in the culture medium was $12 \mathrm{mmol} / \mathrm{l}$. 


\section{Fluorescent bead-based flow cytometric counting of synchronized cells}

Exponentially growing ARIP cells were exposed to thymidine (final concentration $2 \mathrm{mM}$ ) for $12 \mathrm{~h}$, then washed twice, and resuspended in serumcontaining medium. After $12 \mathrm{~h}$ their growth was arrested by incubating the cells in the presence of thymidine (final concentration $2 \mathrm{mM}$ ) for an additional $12 \mathrm{~h}$. After two washings with fresh serum-containing medium, the cells were exposed to normal growth medium, in the presence or absence of GLP-1 (10 nM). GLP-1 was added every $8 \mathrm{~h}$ for different lengths of time $(6,10,14,18,24$, $36,54 \mathrm{~h})$. At the end of the treatment the cells were trypsinized, washed in $5 \mathrm{ml}$ serum-containing medium and resuspended in $1 \%$ paraformaldehyde. Ten microliters of fluorescent bead solution (SpheroTM rainbow fluorescent particles; PharMingen, San Diego, CA, USA) were added to each sample immediately before analysis. Samples were analyzed by FACScan (Becton Dickinson, San Jose, CA, USA) with Cell Quest $3 \cdot 1$ acquisition software (Becton Dickinson). Fluorescent beads were used as a counting reference for the quantitative analysis of cells and then, based on the simultaneous analysis of a fixed number of beads and an unknown number of cells, the following formula was used to calculate the number of cells present in the samples: number of cells $=$ number of counted cells/(number of counted beads/number of beads added $) \times$ volume of the sample.

\section{Cell cycle analysis}

Cell cycle distribution was analyzed by fluorescence-activated cell sorting (FACS) analysis of DNA content. The cells were incubated in serum-free medium with or without GLP-1 $(10 \mathrm{nM})$ for increasing lengths of time, trypsinized, washed in $5 \mathrm{ml}$ serum-containing medium, resuspended in $1 \mathrm{ml}$ cold phophate-buffered saline (PBS) and fixed in cold ethanol $(100 \%)$. Fixed cells were washed with PBS and incubated with propidium iodide $(1 \mu \mathrm{g} / \mathrm{ml}$ in $\mathrm{PBS})$ for $1 \mathrm{~h}$ at room temperature in the dark. Analysis of DNA content in propidium iodide-stained cells was performed by FACScan. Cells were excited at $480 \mathrm{~nm}(15 \mathrm{~mW})$ using an argon ion laser, and red fluorescence (as a measure of the total DNA content) was recorded at $575 / 26 \mathrm{~nm}$ with a band-pass filter. The percentages of cells in G1, S and G2-M phases of the cell cycle were determined using ModFit LT (Verity Software House, Inc, Topsham, Maine).

Cell viability was evaluated by the Trypan blue dye (Gibco-BRL) exclusion technique.

\section{Immunoprecipitation and immunoblotting}

Cells cultured in the presence or absence of GLP-1 were collected and washed twice with cold PBS and lysed in $500 \mu \mathrm{l} \mathrm{M-PER} \mathrm{lysis} \mathrm{buffer} \mathrm{(Pierce,}$ Rockford, IL, USA) containing proteinase inhibitors $(1 \mathrm{mM}$ phenylmethylsufonyl fluoride, $8 \cdot 3 \mu \mathrm{M}$ aprotinin, $50 \mu \mathrm{M}$ leupeptin and $30 \mathrm{mM}$ sodium orthovanadate) (Sigma Chemicals, St Louis, MO, USA) and spun at $90000 \boldsymbol{g}$ for $5 \mathrm{~min}$ at room temperature. The lysate was collected and centrifuged at $13000 \boldsymbol{g}$ for $5 \mathrm{~min}$ at $4{ }^{\circ} \mathrm{C}$. One microgram of control IgG (Santa Cruz Biotechnology, Santa Cruz, CA, USA) together with $20 \mu \mathrm{l}$ Protein-Gagarose (Santa Cruz) were added to the whole cell lysate at $4{ }^{\circ} \mathrm{C}$ for $30 \mathrm{~min}$. The protein concentration was then measured in the supernatant at least twice using the Bio-Rad protein assay reagent (Bio-Rad, Hercules, CA, USA). Soluble proteins (200-500 $\mu \mathrm{g})$ were incubated overnight at $4{ }^{\circ} \mathrm{C}$ a on rotating device with $1 \mu \mathrm{g}$ anti-p27 ${ }^{\mathrm{Kip} 1}$ (Transduction Laboratories, Lexington, KY, USA) or anti-p21 Cip1 (PharMingen, San Diego, CA, USA) and $50 \mu \mathrm{l}$ agarose-conjugated Protein-G. The beads were washed with 10\% M-PER lysis buffer in PBS, and the pellet was resuspended in $30 \mu \mathrm{l}$ electrophoresis sample buffer for immunoblotting.

For immunoblotting, precipitated proteins were separated on $12 \%$ SDS-polyacrylamide gels and transferred onto a nitrocellulose membrane (BioRad). The membranes were then soaked in Poinceau-S solution (Sigma) to verify that an equal amount of proteins was loaded on the gel and the homogeneity of the transfer. After incubation of the membrane with 3\% bovine serum albumin (Sigma) in PBS-Tween 20 (Sigma) for $1 \mathrm{~h}$ at room temperature to inhibit non-specific binding, the membranes were immunoblotted with anti-p2 $7^{\mathrm{Kip} 1}$ (1:1000) or anti- p2 $1^{\text {Cip } 1}(1: 500)$ for $1 \mathrm{~h}$ at room temperature. After three washes in PBS-Tween 20 the membranes were incubated with a secondary antibody conjugate with horseradish peroxidase for $45 \mathrm{~min}$ at room temperature. Immunoreactive proteins were visualized by the ECL immunodetection system (Amersham Pharmacia Biotech, Amersham, Bucks, UK). 
Table 1 PCR primers

\begin{tabular}{|c|c|c|c|}
\hline & Primer sequence & $\begin{array}{l}\text { Size of PCR } \\
\text { product (bp) }\end{array}$ & $\begin{array}{l}\text { Gene Bank } \\
\text { accession number }\end{array}$ \\
\hline \multicolumn{4}{|l|}{ Target gene } \\
\hline Insulin & $\begin{array}{l}\text { CCTGCCCAGGCTTTTGTCAA }(+) \\
\text { CTCCAGTGCCAAGTCTGAA }(-)\end{array}$ & 187 & J00747 \\
\hline GLUT2 & $\begin{array}{l}\text { TTAGCAACTGGGTCTGCAAT(+) } \\
\text { GGTGTAGTCCTACACTCATG(-) }\end{array}$ & 343 & J03145 \\
\hline Glucokinase & $\begin{array}{l}\text { AAGGGAACAACATCGTAGGA }(+) \\
\text { CATTGGCGGTCTTCATAGTA }(-)\end{array}$ & 136 & $\mathrm{AH} 002177$ \\
\hline$\beta$-Actin & $\begin{array}{l}\text { CGTAAAGACCTCTATGCCAA }(+) \\
\text { AGCCATGCCAAATGTCTCAT }(-)\end{array}$ & 349 & V01217 \\
\hline
\end{tabular}

\section{RT-PCR of synchronized cells}

ARIP cells were synchronized as described for cell counting and then exposed to F12 medium, in the presence of GLP-1 (10 nM/l). GLP-1 was added every $8 \mathrm{~h}$, and cells were harvested after 12, 24, 30, $36,44,50,56,68$ or $74 \mathrm{~h}$. At the end of the treatment the culture medium was removed and the cells were washed twice with serum-free medium. Total RNA was extracted using the TRiazol-method (Gibco-BRL), and treated with DNase (amplification grade; Gibco-BRL) in $20 \mathrm{mmol} / \mathrm{l}$ Tris-HCl (pH 8·4), 2 mmol/l $\mathrm{MgCl}_{2}$ and $50 \mathrm{mmol} / \mathrm{l} \mathrm{KCl}$ to remove any trace of contaminating genomic DNA. RNA $(2 \cdot 5 \mu \mathrm{g})$ was then subjected to reverse transcription (RT reagents; Promega, Madison, WI, USA). RT-PCR was undertaken in a volume of $50 \mu \mathrm{l}$ buffer containing $50 \mathrm{mmol} / \mathrm{K} \mathrm{KCl}, 10 \mathrm{mmol} / \mathrm{l}$ Tris- $\mathrm{HCl}$, $3.5 \mathrm{mmol} / \mathrm{l} \mathrm{MgCl}_{2}, 200 \mu \mathrm{mol} / \mathrm{l}$ each dNTPs (Gibco-BRL) and $0.4 \mu \mathrm{mol} / \mathrm{l}$ each of sense and antisense primers to rat insulin. Amplification was performed for 30 cycles at the denaturing temperature of $94{ }^{\circ} \mathrm{C}$ for $1 \mathrm{~min}$, annealing temperature of $60{ }^{\circ} \mathrm{C}$ for $45 \mathrm{~s}$ and an extension temperature of $72{ }^{\circ} \mathrm{C}$ for $1 \mathrm{~min}$. For the amplification of the glucose transporter (GLUT)-2 and glucokinase mRNAs, we used the same PCR conditions as described above, in the presence of gene-specific primers. For $\beta$-actin, the annealing temperature was raised to $64{ }^{\circ} \mathrm{C}$ for $1 \mathrm{~min}$ and gene-specific primers were used. All other experimental conditions to amplify GLUT-2 and glucokinase mRNAs were identical to those described for the amplification of insulin mRNA. Oligonucleotide primers for insulin, GLUT-2, glucokinase and $\beta$-actin were derived from the published gene sequences (Ullrich et al. 1977, Nudel et al. 1983, Thorens et al. 1988, Magnuson et al. 1989) and are presented in Table 1.

\section{Immunofluorescence microscopy}

ARIP cells were grown in monocoated chamber slides (Nange Nunc International, Naperville, IL, USA) in the presence or absence of GLP-1 (10 nM) for $0,12,24$ or 48 . The cells were then washed in PBS and fixed with paraformaldehyde 4\% (Sigma) for $30 \mathrm{~min}$ at $37^{\circ} \mathrm{C}$ in PBS. After three washings in PBS, they were permeabilized with $0 \cdot 1 \%(\mathrm{v} / \mathrm{v})$ Triton X-100 in PBS for $10 \mathrm{~min}$. The cells were then incubated sequentially with $10 \%$ normal blocking serum in PBS (Santa Cruz) for $20 \mathrm{~min}$, followed by overnight incubation with guinea pig anti-porcine insulin antibody (Dako, Carpinteria, CA, USA) at a dilution of 1:125, or with mouse anti-human cytokeratin 20 (CK-20; Novocastra, Newcastle upon Tyne, UK) at a dilution of 1:50, at $4{ }^{\circ} \mathrm{C}$, in a humid chamber. After three washes in PBS, the cells were incubated with Texas Red-conjugated rabbit anti-guinea pig IgG (Vector Laboratories, Inc., Burlingame, CA, USA) $(1: 200)$ for insulin detection and fluorescein isothyiocyanate (FITG)-conjugated goat anti-mouse IgG (Chemicon, Temecula, CA, USA) (1:50) for CK-20 detection. The secondary antibody incubations were $1 \mathrm{~h}$ at room temperature in a humid chamber. Slides were mounted with a medium containing 4',6 diamidino-2-phenylindole (Vectashield; Vector Laboratories) and examined using a fluorescent microscope (Olympus AX-70, Olympus America Inc., Melville, NY, USA). Images were captured by Apogee Digital Camera (Olympus America Inc) and processed by the 


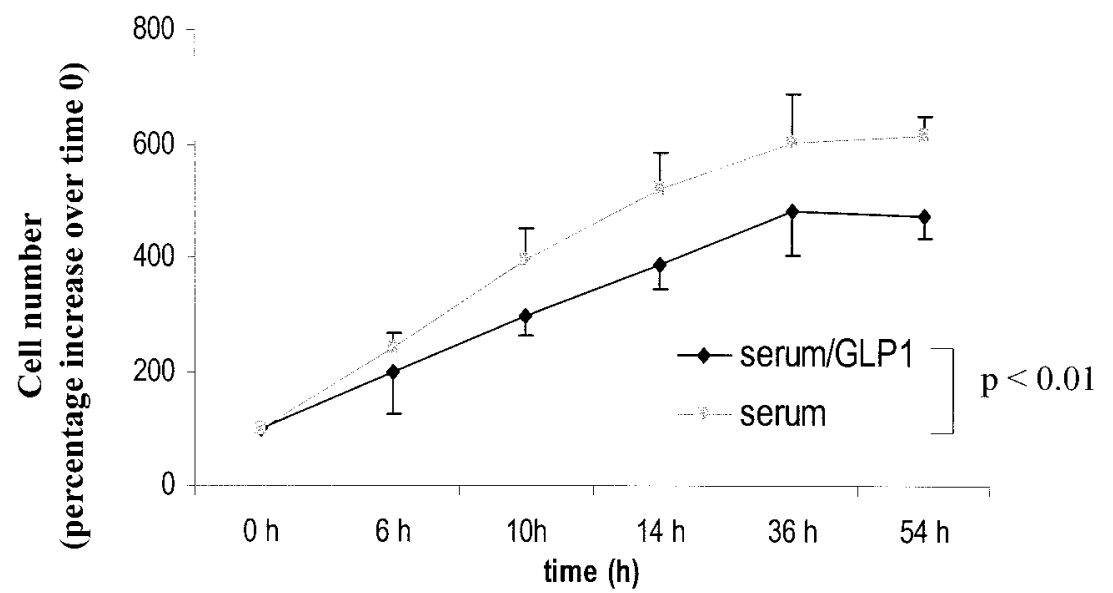

Figure 1 Cell counting by fluorescent bead-based flow cytometry. Exponentially growing ARIP cells were double synchronized with thymidine and exposed to serum containing F12 medium in the presence or absence of GLP-1 (10 nM) for different lengths of time. Fluorescent beads were used as a counting reference for the quantitative analysis of cells by FACS analysis. Statistical differences between GLP-1-treated and control cultures were evaluated by ANOVA. The $P$ value on the Figure refers to the difference between the two curves.

Image-Pro Computer software (Mediacybernetics, Carlsbad, CA, USA).

Staining for insulin and CK-20 experiments was repeated at least three times, using independent cultures.

Control staining for insulin (islets of Langerhans) and CK-20 (pancreatic ductal epithelium) was performed using normal rat pancreas.

\section{HPLC analysis}

The culture media of ARIP cells grown in the presence of GLP-1 (or vehicle) for $48 \mathrm{~h}$ was utilized for HPLG for insulin, following the procedure described by Khaksa et al. (1998). In brief, $1 \mathrm{ml}$ of the cell culture medium was removed and treated with $1 \mathrm{ml}$ dichloromethane by rotating for $5 \mathrm{~min}$. The supernatant layer was decanted and the organic layer transferred to an HPLC sample tube and a $20 \mathrm{ml}$ aliquot injected into the C18 reverse phase HPLG column (Nova-Pak; Waters Corporation, Milford, MA, USA) for chromatographic separation. The mobile phase consisted of $90 \%$ methanol/water $(50 \% \mathrm{v} / \mathrm{v})$ and $10 \%$ glacial acetic acid. A Finnegan LCQ Deca ion trap mass spectrometer (Thermo Finnigan, San Jose, CA, USA) connected to the HPLC column was used to analyze mass distribution of alleles of rat insulin secreted in response to GLP-1 treatment. Insulin was ionized using electro-spray ionization and analyzed in normal mass range (m/z 200-2000) operation mode to recover the multiple charged peptide alleles. Control rat insulin was used as standards.

\section{Regulation of insulin secretion by glucose}

Cells were plated at a density of $10^{6}$ cells/well in a 6 -well plate. Once they reached $80 \%$ of confluence they were washed with serum-free medium containing $12 \mathrm{mM}$ glucose and then exposed to medium containing increasing concentrations of glucose. Glucose-dependent insulin secretion was evaluated in the presence of a determined concentration of GLP-1 (10 nM for $48 \mathrm{~h}$ ) with increasing concentrations of glucose in the culture medium $(0,1,6,10$ and $20 \mathrm{nM}$ ). Insulin released into the medium was measured by radioimmunoassay (RIA) (Linco Research Inc., St Charles, MA, USA). Total insulin accumulation in the culture medium was then normalized for total cellular protein content for each individual culture.

\section{Protein assay}

Total cellular protein content was measured by utilizing the Bradford method (Bio-Rad). The 


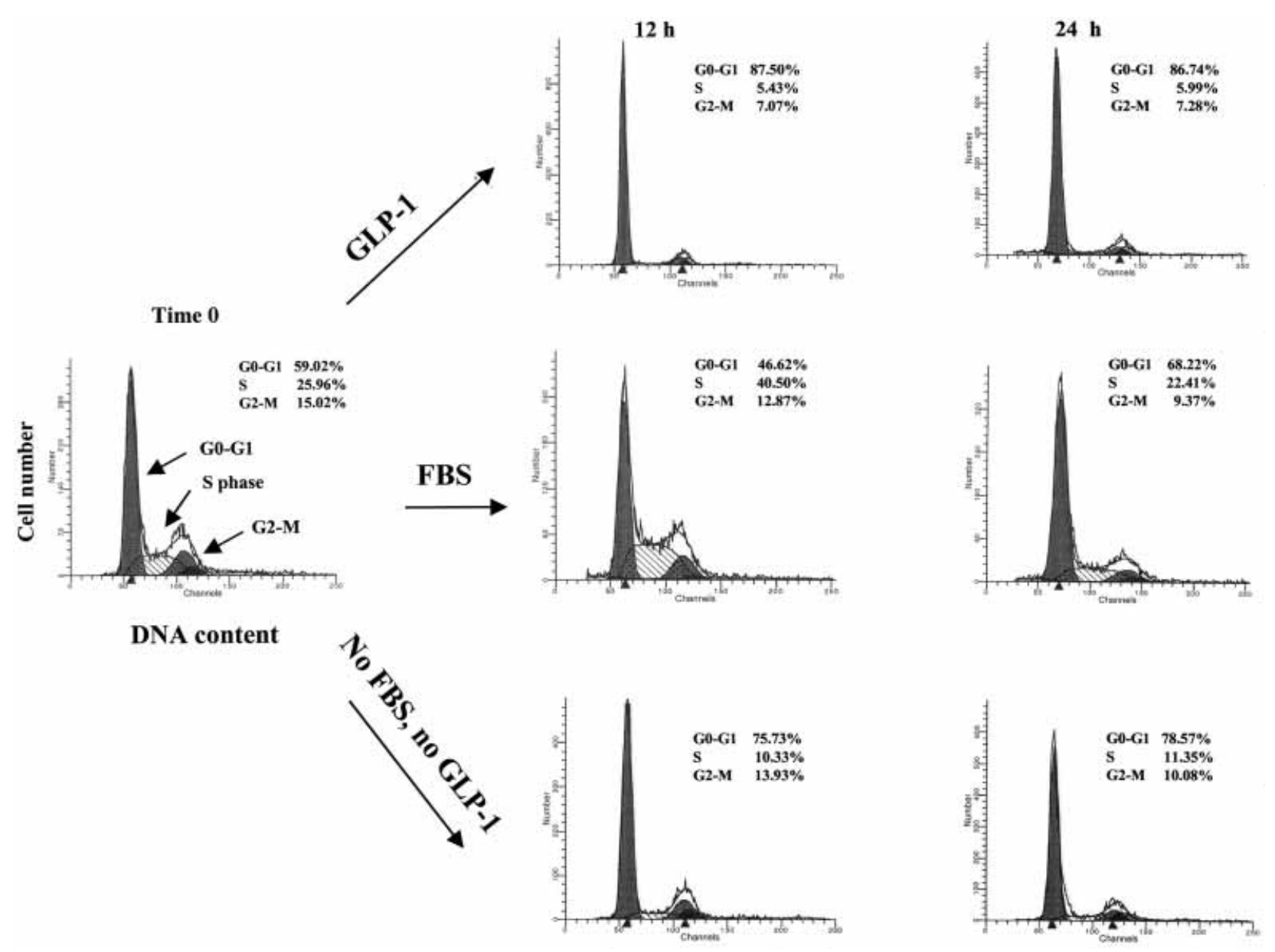

Figure 2 Flow cytometry for cell cycle analysis. ARIP cells were cultured in serum-free medium and then treated with GLP-1 (10 nM) for increasing lengths of time. Cells cultured in serum-free medium or in medium containing serum were used as controls. The Figure depicts a representative FACscan experiment. In each graph the cell number is plotted on the vertical axis and the channel number (i.e. channel of fluorescence emission) on the horizontal axis. Since the intensity of fluorescence is directly proportional to the amount of DNA per cell, the trace gives a distribution analysis of the cell population by DNA content. The percentages of cells in G1, S and G2-M phases of the cell cycle, as determined by Lysis II software analysis, are shown in each individual graph.

amount of protein measured was used as a correction factor for determining the relative amount of medium to be assayed for each individual RIA for insulin.

\section{Statistical analysis}

The data are expressed as means \pm S.E.M. Significance was evaluated by unpaired Student's $t$-test. One-way analysis of variance (ANOVA) was used to evaluate statistical significance when more than two data points were analyzed. Statistical significance by either unpaired Student's $t$-test or
ANOVA is explicitly identified in the text or in the Figure legends.

\section{Results}

\section{Fluorescent bead-based flow cytometry for cell counting}

Cell counting demonstrated that there were fewer cells in cultures grown in the presence of GLP-1, compared with controls (Fig. 1). After $6 \mathrm{~h}$ from the beginning of the treatment with GLP-1 the number of cells was $17 \%$ lower in the GLP-1-treated 
culture in comparison with cultures where only the vehicle was added. The difference between the number of cells grown in the presence and those grown in the absence of GLP-1 reached 25\% after $10 \mathrm{~h}$ of exposure $(P<0.05$; by Student's $t$-test comparing cell number of GLP-1-treated vs control cultures at $10 \mathrm{~h}$ ) and was maintained over time up to $54 \mathrm{~h}$ from the earliest exposure to GLP-1 $(P<0 \cdot 01$; by ANOVA comparing curves derived from GLP-1-treated vs untreated cultures).

\section{Cell cycle distribution}

The effect of GLP-1 on cell cycle progression of ARIP cells was analyzed by FACS. Exposure to GLP-1 lowered the proportion of cells in $\mathrm{S}$ phase compared with control cultures (Fig. 2). After $12 \mathrm{~h}$ from the beginning of the treatment with GLP-1, $9 \%$ of the cell population was in $\mathrm{S}$ phase of the cell cycle, and reached $11 \%$ after $24 \mathrm{~h}$. This was lower than the proportion of cells that were in $\mathrm{S}$ phase in the cultures grown with vehicle alone in the absence of FBS $(16 \%$ and $13 \%$ at 12 and $24 \mathrm{~h}$ respectively; $P<0.05$ at $12 \mathrm{~h}$, not significant at $24 \mathrm{~h})$, or in the presence of $10 \% \operatorname{FBS}(37 \%$ and $25 \%$ at 12 and 24 h respectively; $P<0.01$ for both 12- and 24-h time-points). An average of three independent experiments revealed a $43 \%$ reduction of cells in $\mathrm{S}$ phase at $12 \mathrm{~h}$ and a $15 \%$ reduction of cells in S phase after $24 \mathrm{~h}$ of treatment with GLP-1 compared with control cultures grown in the absence of FBS. The mean reduction of GLP-1treated cells that were in $\mathrm{S}$ phase in comparison with cells grown in FBS alone was about $75 \%$ at $12 \mathrm{~h}$ and $56 \%$ at $24 \mathrm{~h} \quad(P<0.001$ and $P<0.01$ respectively). We also observed a parallel increase of the percentage of GLP-1-treated cells in G1 phase $(84 \%$ at $12 \mathrm{~h}$ and $77 \%$ at $24 \mathrm{~h})$ compared with cells grown in serum-free medium $(68 \%$ and $74 \%$ at 12 and $24 \mathrm{~h}$ respectively) and with cells grown in FBS $(54 \%$ and $55 \%$ at 12 and $24 \mathrm{~h}$ respectively) (Figs 2 and 3; $P<0.01$ for GLP-1treated vs serum-free medium at $12 \mathrm{~h} ; P<0.05$ for GLP-1-treated vs FBS at $12 \mathrm{~h} ; P<0.05$ for GLP-1-treated vs FBS at $24 \mathrm{~h}$; not significant GLP-1-treated vs serum-free medium at $24 \mathrm{~h}$ ). An effect of GLP-1 treatment on the proportion of cells in G2-M phase was also observed (Figs 2 and 3). Indeed, $6 \cdot 5 \%$ of the GLP-1-treated cells were in G2-M phase at $12 \mathrm{~h}$ and $11 \%$ at $24 \mathrm{~h}$, compared with $15 \cdot 5 \%$ and $12 \cdot 5 \%$ of the cells grown in the
S phase
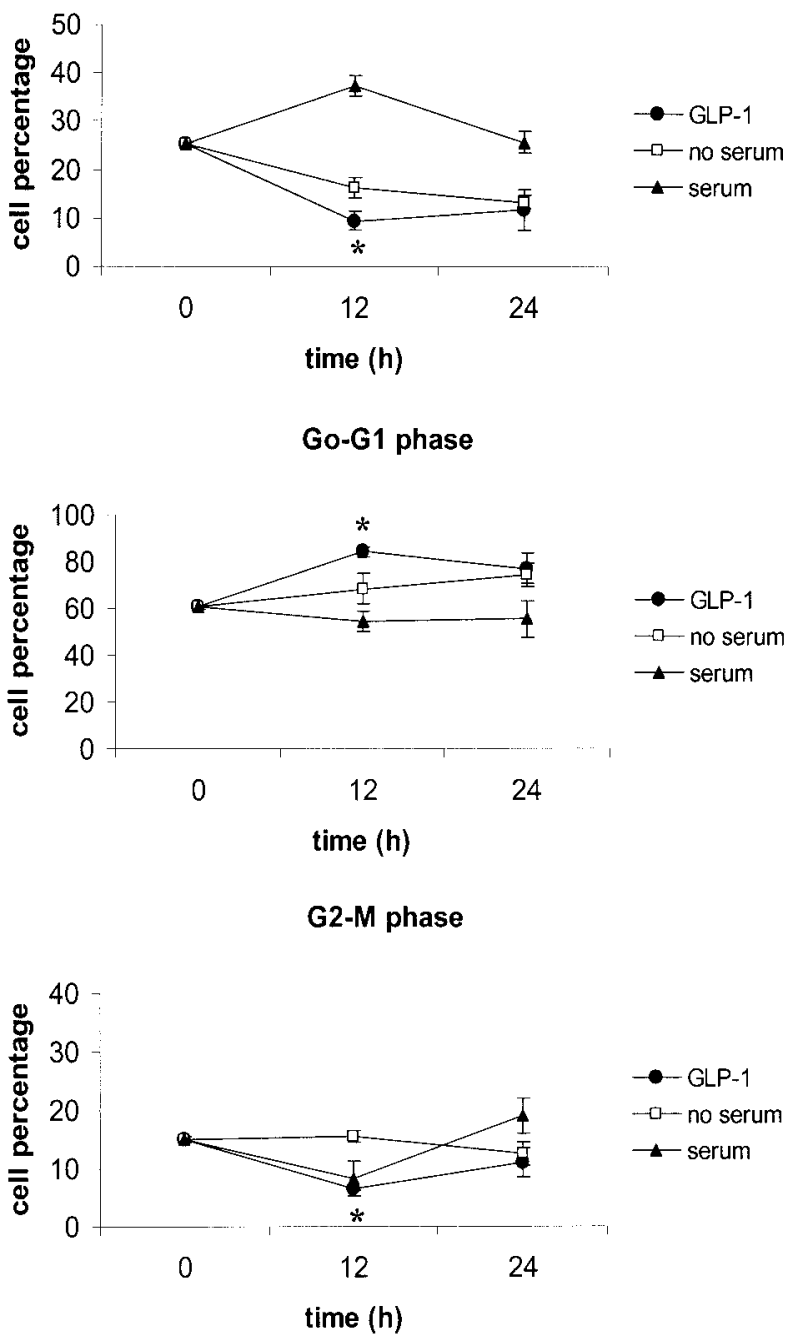

Figure 3 Percentage of cells in the different phases of the cell cycle at each time-point for each experimental condition, as derived by FACS analysis. The graphs represent the average of three independent experiments. Statistical significance of the data was evaluated by unpaired Student's $t$-test. Asterisks indicate individual time-points at which GLP-1-treated cells showed a significant cell cycle distribution compared with cells cultured in the absence of serum. Cells cultured in the presence of FBS are shown as controls for actively growing cells.

presence of the vehicle alone, $8 \%$ and $19 \%$ of the cells grown in medium containing FBS $(P<0.01$ for GLP-1-treated vs serum-free medium at $12 \mathrm{~h}$; not significant for GLP-1-treated vs serum-free medium at $24 \mathrm{~h} ; P<0.05$ for GLP-1-treated vs FBS at $12 \mathrm{~h} ; P<0.01$ for GLP-1-treated vs FBS at $24 \mathrm{~h}$; 


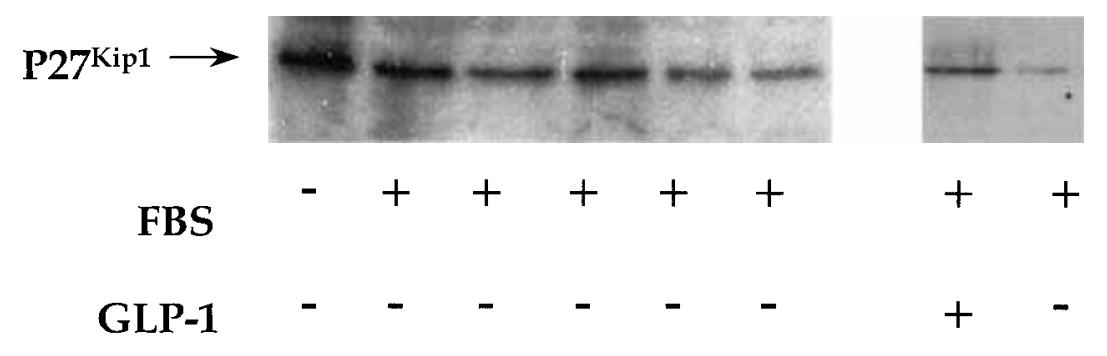

\section{$\begin{array}{llllllllll}\text { Time (h) } & 0 & 2 & 6 & 8 & 12 & 24 & 48 & 48\end{array}$}

Figure 4 Western blot analysis of p27 ${ }^{\text {Kip } 1}$. ARIP cells were serum starved for $24 \mathrm{~h}$ and then re-exposed to serum-containing medium for $24 \mathrm{~h}$ before incubation with GLP-1 (10 nM) for $24 \mathrm{~h}$. Total cell lysates were immunoprecipitated with anti-p27 ${ }^{\mathrm{Kip} 1}$ antibody and resolved on $12 \%$ SDS-polyacrylamide gel. This experiment was repeated four times providing results very similar to the one depicted in this blot.

not significant for GLP-1-treated vs serum-free medium at $24 \mathrm{~h}$ ). The difference in cell cycle distribution between GLP-1-treated and control cultures progressively declined over time, losing statistical significance after $48 \mathrm{~h}$.

\section{Effects of GLP-1 on the expression of G1 Cdk inhibitors, p27 Kip1 and p21 Cip1}

After the induction of growth arrest by a 24-h serum starvation (time 0), cells were re-exposed to serum-containing medium for $24 \mathrm{~h}$ and subsequently grown for another $24 \mathrm{~h}$ in the presence or absence of GLP-1 $(10 \mathrm{nM})$. As shown in Fig. 4, p27 $7^{\mathrm{Kip} 1}$, abundantly expressed in growth-arrested cells, was down-regulated by a 24-h exposure to serum-containing medium. The addition of GLP-1 resulted in an up-regulation of p2 $7^{\text {Kip } 1}$, occurring within $24 \mathrm{~h}$ of GLP-1 treatment. By contrast, in the control cells, grown in the absence of GLP-1, the $\mathrm{p} 27^{\mathrm{Kip} 1}$ protein remained at a low level over time.

The expression of another member of the Kip/Cip family of Cdk inhibitors, p2 ${ }^{\text {Cip }}$, was also

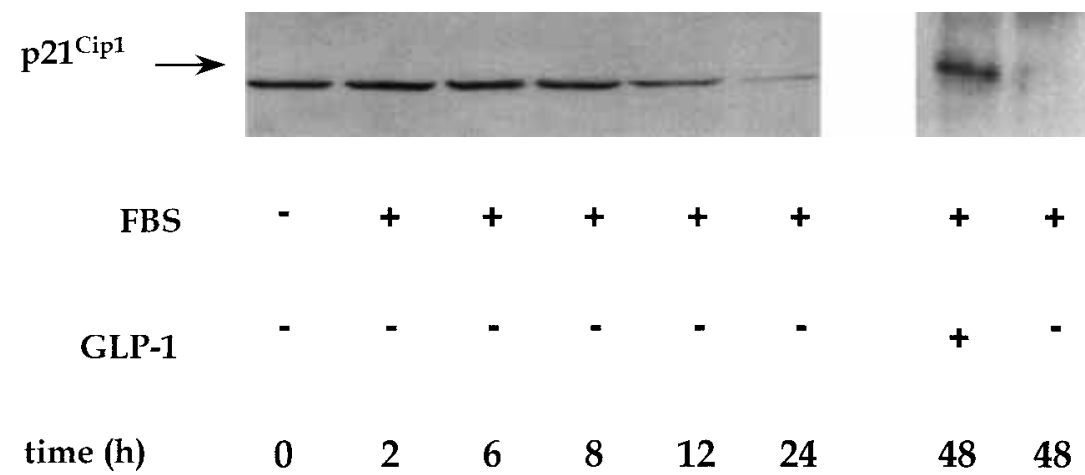

Figure 5 Western blot analysis of p21 ${ }^{\mathrm{Cip} 1}$. ARIP cells were serum starved for $24 \mathrm{~h}$ and then re-exposed to serum-containing medium for $24 \mathrm{~h}$ before incubation with GLP-1 $(10 \mathrm{nM})$ for $24 \mathrm{~h}$. Total cell lysates were immunoprecipitated with anti-p21 ${ }^{\text {Cip } 1}$ antibody and resolved on $12 \%$ SDS-polyacrylamide gel. This experiment was repeated four times providing results very similar to the one depicted in this blot. 


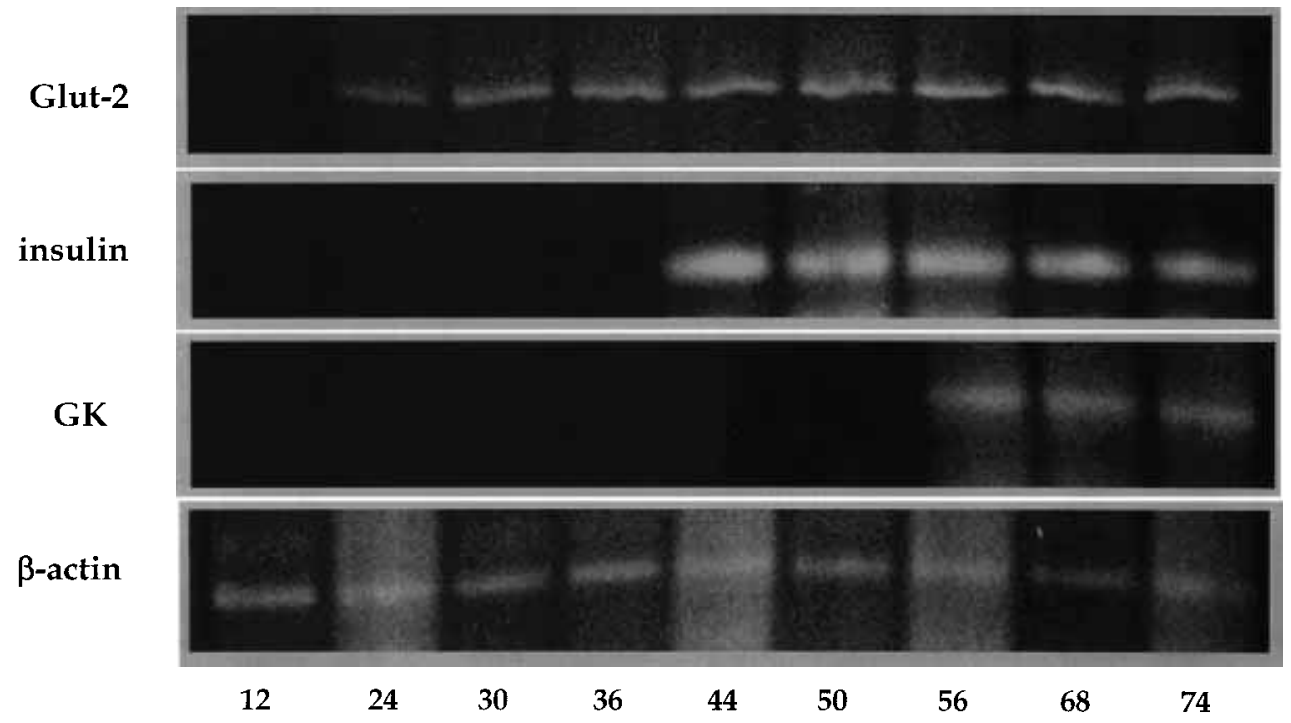

time (h)

Figure 6 RT-PCR for $\beta$-cell-specific transcripts. ARIP cells growing exponentially were double synchronized using thymidine and exposed to GLP-1 (10 nM) every $8 \mathrm{~h}$ for different lengths of time. Total RNA was extracted from each culture at different time-points and analyzed by RT-PCR for the expression of GLUT-2, insulin and glucokinase (GK) mRNA. Each experiment was repeated three times, using RNA samples from independent cultures.

examined. As shown in Fig. 5, p21 Cip was expressed in growth-arrested cells and was downregulated by a 24-h exposure to serum-containing medium. As for $\mathrm{p} 27^{\mathrm{Kip} 1}$ protein, the addition of GLP-1 resulted in an up-regulation of $\mathrm{p} 21^{\text {Cip }}$ protein expression at $24 \mathrm{~h}$ from the beginning of GLP-1 treatment. In contrast to GLP-1-treated cells, control cells maintained a drastic reduction of $\mathrm{p} 21^{\mathrm{Cip}}$ level, likely due to the re-exposure to serum-containing medium.

\section{GLP-1 promoted the expression of $\beta$-cell-specific genes in synchronized cells}

RT-PCR analysis revealed the earliest detection of insulin mRNA after $44 \mathrm{~h}$ from the beginning of GLP-1 treatment of growth-arrested cells (Fig. 6). Insulin mRNA level remained constant up to $74 \mathrm{~h}$ after the first GLP-1 exposure. RT-PCR for GLUT-2 revealed the presence of this transcript after only $24 \mathrm{~h}$ of treatment with GLP-1, preceding the earliest detection of insulin mRNA by approximately 1 day. After the initial expression at
24 h, GLUT-2 mRNA remained constant over time. Glucokinase mRNA was first detectable at $56 \mathrm{~h}, 12 \mathrm{~h}$ after the detection of insulin, its levels also remained unchanged after the first detection. No RT-PCR products for insulin, GLUT-2 or glucokinase were detectable in non-GLP-1-treated cells. RT-PCR for $\beta$-actin was used as a control for cDNA loading.

\section{Immunocytochemistry and immunofluorescence microscopy}

Treatment with GLP-1 induced the differentiation of ductal epithelial cells into insulin-expressing cells. As shown in Fig. 7, no insulin immunoreactivity was observed prior to treating ARIP cells with GLP-1. Insulin was first detected in a few cells after $12 \mathrm{~h}$ of GLP-1 treatment. At $24 \mathrm{~h}$ from the early exposure to GLP-1, there was a greater number of cells that contained insulin. We also observed a time-dependent increase in insulin immunoreactivity per individual cell, suggesting an accumulation of insulin over time. 


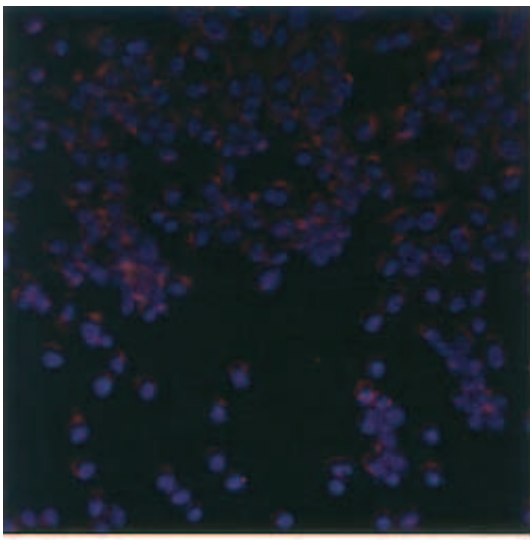

0 h

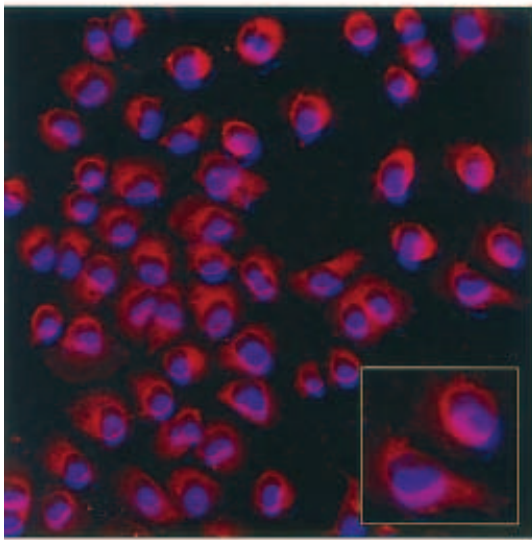

$48 \mathrm{~h}$

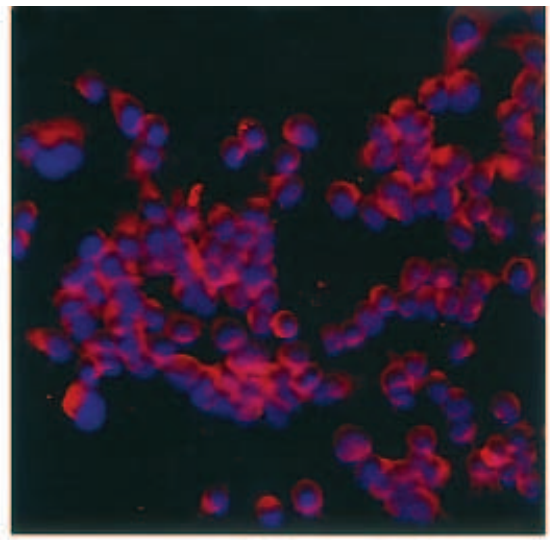

$12 \mathrm{~h}$

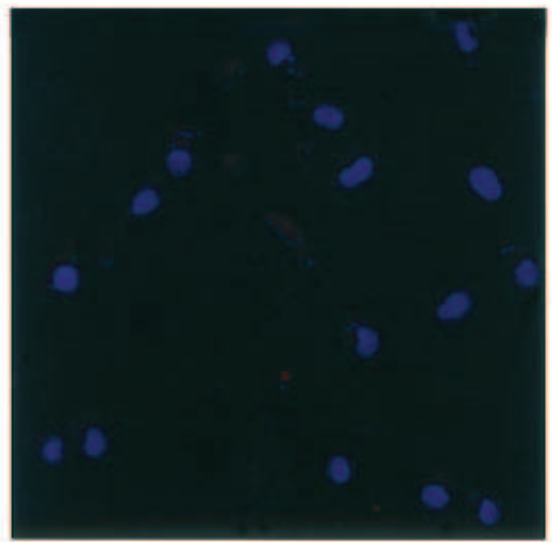

blank

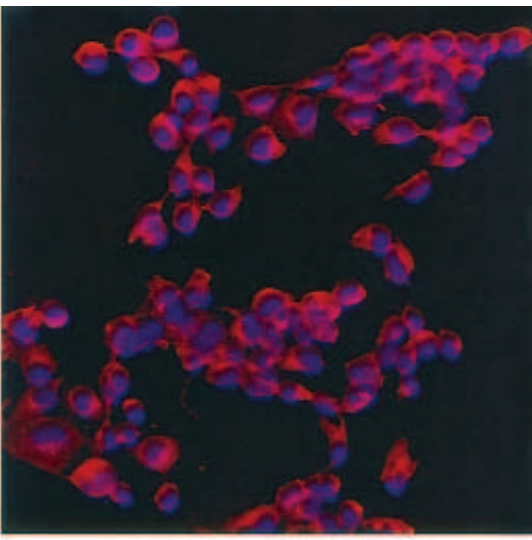

24 h

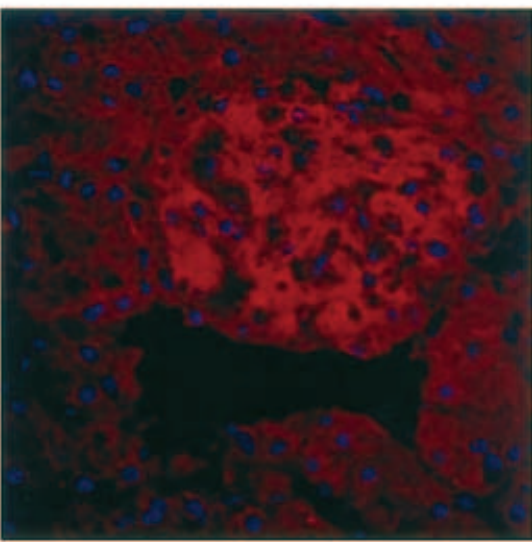

rat pancreas

Figure 7 Immunocytochemistry for insulin. ARIP cells were cultured with GLP-1 (10 nM) for $48 \mathrm{~h}$. ARIP cells treated with GLP-1 (10 nM for $48 \mathrm{~h}$ ) and stained solely with secondary antibody were used as negative control (blank). Rat pancreas with characteristic islets of Langerhans was used as positive control. This experiment was repeated three times providing results very similar to the one depicted here. Pictures were taken at $20 \times$ magnification. The boxed area in the $48 \mathrm{~h}$ panel shows a greater magnification $(40 \times)$ of two individual cells.

As cells acquired a $\beta$-cell-like phenotype, with the capability of producing insulin, we observed a progressive reduction of the expression of CK-20, a protein marker of ductal epithelial cells. As shown in Fig. 8, a positive staining for CK-20 was detected in the entire population of ARIP cells prior to the exposure to GLP-1; however, the expression of CK-20 was strongly reduced after $24 \mathrm{~h}$ of treatment with GLP-1, with few cells being still immunoreactive with the CK-20 antibody at later time-points.

\section{HPLC analysis for insulin}

HPLC analysis of culture medium revealed the presence of the two non-allelelic rat insulin proteins (insulin-I and insulin-II) secreted by ARIP cells when grown in the presence of GLP-1 (Fig. 9A and B). Control cultures, treated with vehicle only, did not produce chromatographic rat insulin peaks indicating that no insulin synthesis was induced in untreated cultures.

\section{Glucose-dependent secretion of insulin}

Cells cultured in the presence of increasing concentrations of glucose were able to release insulin in a glucose-dependent manner when exposed to GLP-1 (Fig. 9G). No insulin secretory response was observed when cells were cultured with vehicle alone. The lowest concentration of glucose required to induce the secretion of insulin was $3 \mathrm{mM}$, this was followed by a progressive increase in insulin accumulation into 


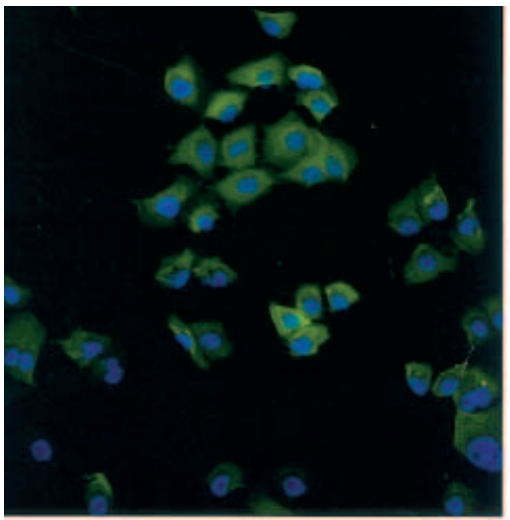

O h

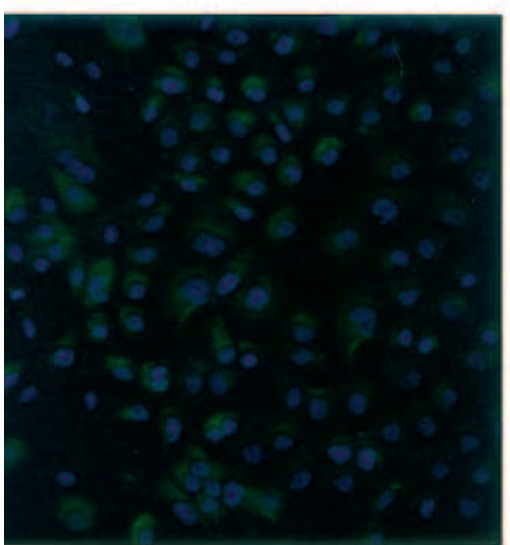

$48 \mathrm{~h}$

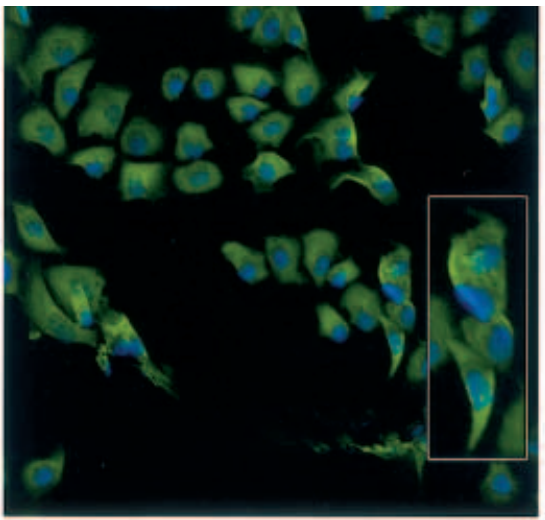

12 h

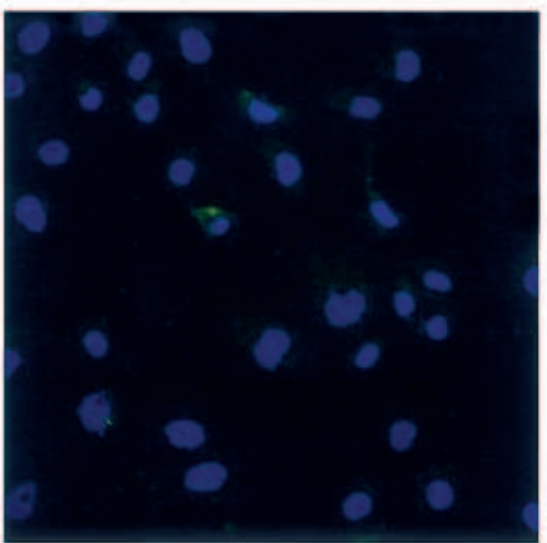

blank

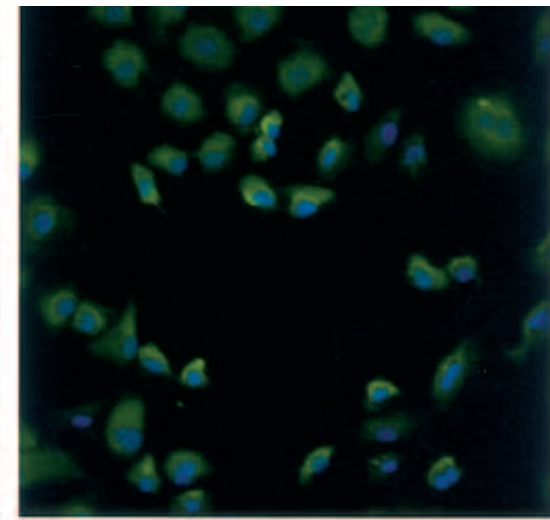

$24 \mathrm{~h}$

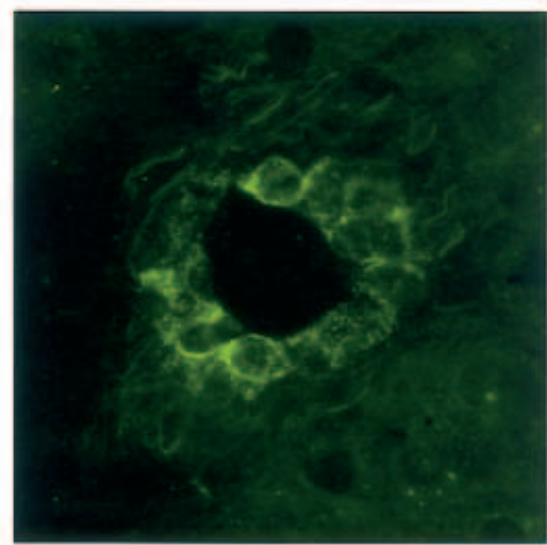

rat pancreas

Figure 8 Immunocytochemistry for CK-20. ARIP cells cultured with GLP-1 (10 nM) for $48 \mathrm{~h}$. ARIP cells treated with GLP-1 (10 nM for $48 \mathrm{~h}$ ) and stained solely with secondary antibody were used as negative control (blank). Rat pancreas with characteristic ductal epithelial cells was used as positive control. This experiment was repeated three times providing results very similar to the one depicted here. Pictures taken at $20 \times$ magnification. The boxed area in the $12 \mathrm{~h}$ panel shows a greater magnification $(40 \mathrm{x})$ of two individual cells.

the culture, with a plateau detected with glucose concentrations between 10 and $20 \mathrm{mM}$.

\section{Discussion}

In this study we have demonstrated that the exposure of pancreatic ductal cells to GLP-1 induced a cell cycle re-distribution leading to their differentiation into insulin-producing cells. Treatment with GLP-1 was associated with an up-regulation of the G1 phase cyclin-Cdk inhibitors, p2 ${ }^{\mathrm{Kip} 1}$ and $\mathrm{p} 21^{\mathrm{Cip}}$. As cells slowed down their proliferation rate, a time-dependent transition from a ductal-like phenotype to the acquisition of $\beta$-cell-like characteristics was also demonstrated.
The intestinal hormone GLP-1 has been shown to play an important role in the expansion of islet cell mass in animal models of glucose intolerance and diabetes (Wang et al. 1997, Pederson et al. 1998, Xu et al. 1999, Perfetti et al. 2000, Stoffers et al. 2000). The improvement of glucose tolerance that followed the administration of GLP-1 was shown to result from the neo-differentiation of pancreatic ductal cells into insulin-expressing cells (Xu et al. 1999, Stoffers et al. 2000). In the present study, we elected to use a rat pancreatic ductal cell line, termed ARIP, as a biological model to characterize some of the events leading to the trans-differentiation of ductal cell into insulinproducing cells. 
A

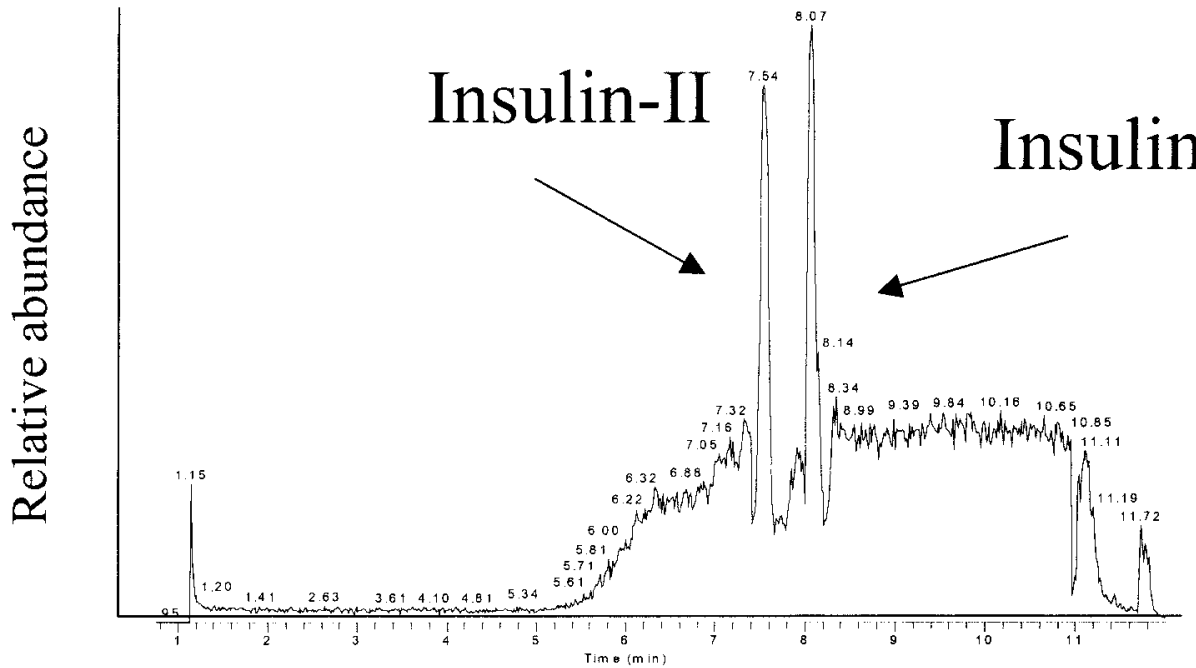

B

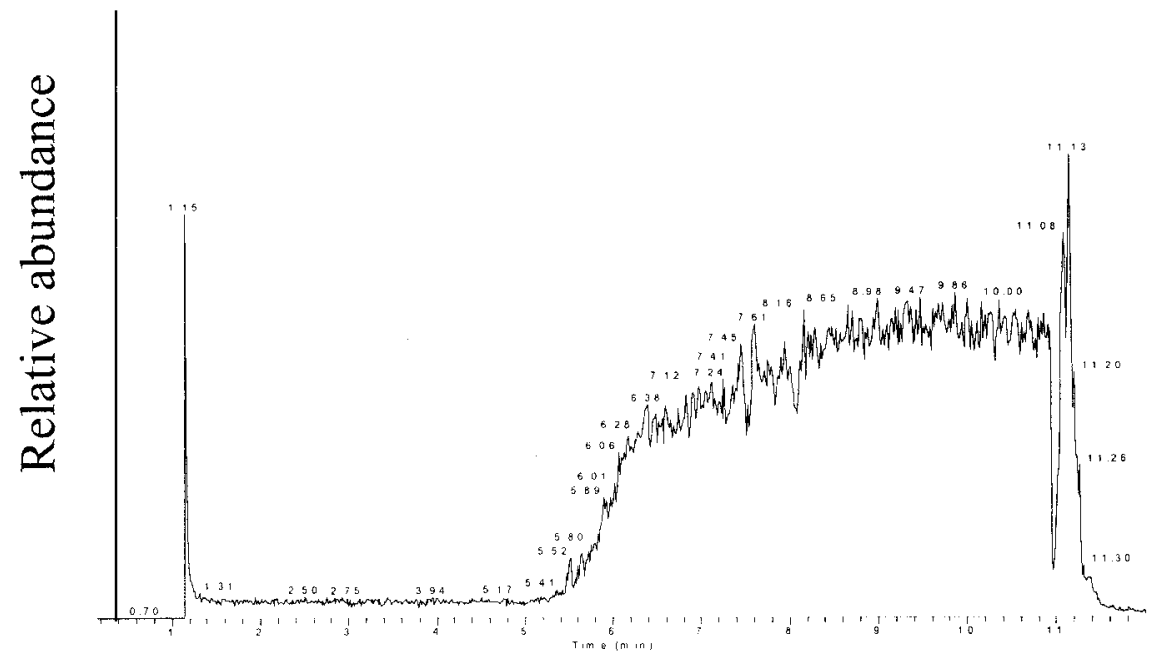

$\mathrm{C}$

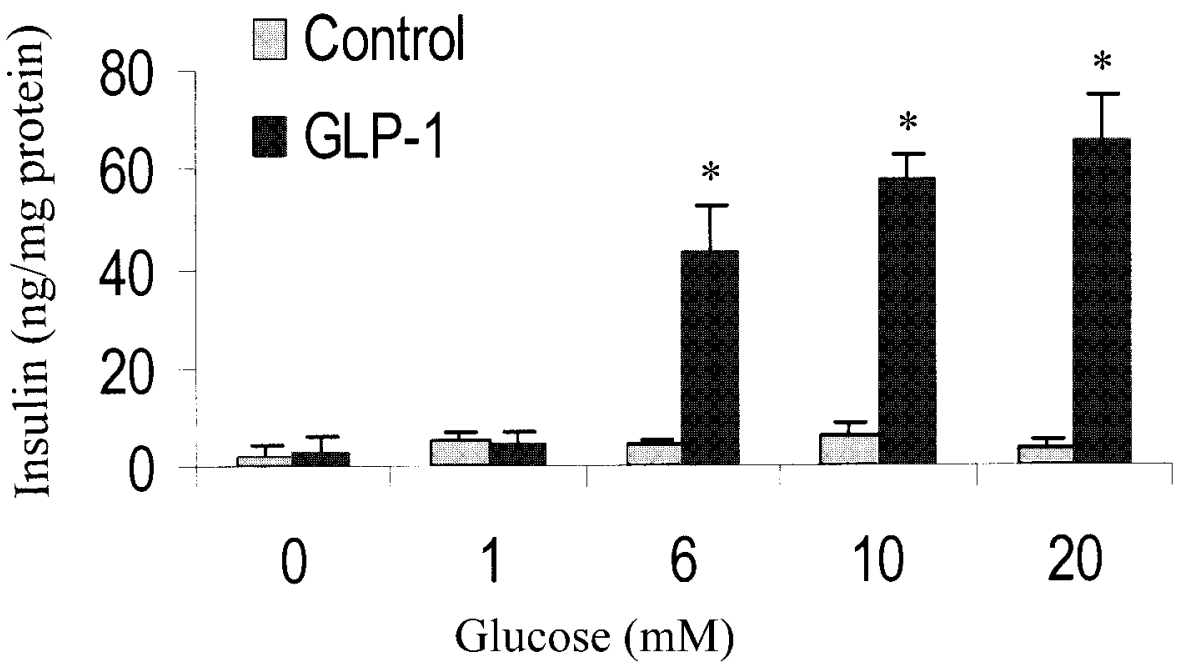


Differentiation of mammalian cells characteristically follows a slow-down of the cell proliferation rate and exit from the cell cycle (Coffman \& Studzinski 1999). Initial experiments were therefore performed to investigate the effect of GLP-1 on cell proliferation and to characterize its effect on the distribution of cells in different phases of the cell cycle. The number of cells present in the GLP-1-treated cultures was significantly lower than in controls. Furthermore, the population of cells entering in $\mathrm{S}$ phase was substantially reduced by GLP-1, while an increase in the percentage of resting cells in G0-G1 phase and a reduction in mitotic cells in G2 phase occurred.

The potential control by cell cycle modulators (i.e. hormones, growth factors, etc.) takes place at different and defined check points of the cell cycle (Pestell et al. 1999). The transition between G1 and $\mathrm{S}$ phase is one of the most important regulated steps in this process (Reed 1996). Entering S phase is strictly regulated in the early and late G1 phase by the balance between cell cycle activators (Cdks) and cell cycle inhibitors (Sherr 1994, Sherr \& Roberts 1995). Progression through G1 phase requires the activity of the cyclin D-dependent kinases, Gdk4 and/or Gdk6, early in G1 and the cyclin E-dependent kinase, Gdk2, in the later G1 phase. Cdk inhibitors can prevent the activation of Cdks by binding the cyclin-Cdk complexes and thus preventing cells from entering $\mathrm{S}$ phase. Among the Cdk inhibitors, p27 Kip 1 and p2 $1^{\text {Cip } 1}{ }^{1}$ have been shown to inhibit a wide variety of cyclin-Cdk complexes in vitro. We therefore investigated whether the pro-differentiation property of GLP-1 required a GLP-1-dependent regulation of the growth-arrest signaling proteins $\mathrm{p} 27^{\mathrm{Kip} 1}$ and p21 Cip1 (Polyak et al. 1994a,b, Toyoshima \& Hunter 1994, Harper et al. 1995) Our data demonstrated that the levels of the two proteins were both increased by GLP-1, thus showing that the up-regulation of these Cdk inhibitors is one of the molecular mechanisms underlying the cell cycle modulation by GLP-1.

It is likely that the transition from the phenotype of ductal cells into that of insulin-producing cells requires that a complex network of genes and their products is activated/deactivated in a finely co-ordinated fashion in order to ensure that a proper differentiation process takes place. We have demonstrated that GLP-1 induced a timedependent reduction of the duct cell specific marker, CK-20, and this was associated with a progressive increase in the synthesis of insulin. In addition to insulin, GLP-1 induced a timedependent expression of two other main regulators of the glucose-sensing machine of normal $\beta$-cells, the glucose transporter, GLUT-2, and the glucosephosphorylating enzyme, glucokinase. Finally the acquisition of a $\beta$-cell-like phenotype was associated with the capability of a glucose-dependent secretion of insulin into the culture medium.

In summary, the present study elucidates some of the early events that allow GLP-1 to slow down cell growth in order to promote their differentiation into insulin-secreting cells.

\section{Acknowledgements}

We should like to thank Patricia Lin and Bill Pollard for their technical assistance. This study was supported, in part, by the Foundation for Diabetes Research.

\section{References}

Anastasi E, Ponte E, Gradini R, Bulotta A, Sale P, Tiberti C, Okamoto H, Dotta F \& Di Mario U 1999 Reg and cytokeratin 20 expression during ductal cell differentiation and proliferation in a mouse model of autoimmune diabetes. European fournal of Endocrinology $141644-652$.

Bonner-Weir S 1994 Regulation of pancreatic $\beta$-cell mass in vivo. Recent Progress in Hormone Research 49 91-104.

Figure 9 HPLC and RIA for insulin. ARIP cells cultured in the presence of $10 \mathrm{mM}$ glucose with GLP-1 (10 nM) or vehicle for $48 \mathrm{~h}$ were subjected to HPLC analysis. Cells cultured in the presence of GLP-1 revealed the presence (retention time $7.53 \mathrm{~min}$ ) of the two known non-allelelic rat insulin proteins (insulin-I and insulin-II) (A), while no insulin was detected in control cultures (B). Repetition of HPLC analysis in the independent cultures of GLP-1-treated and controls showed very similar results. To study the cell responsiveness to glucose, ARIP cells were cultured in serum-free medium with GLP-1 (10 nM for $48 \mathrm{~h}$ ) or vehicle in the presence of various concentrations of glucose $(0$, 1, 6, 10 and $20 \mathrm{mM})(\mathrm{C})$. Each experiment was repeated three times and the data represent the means \pm s.D. Insulin levels were normalized for total protein content in each individual sample of culture medium. ${ }^{*} P<0.001$ for GLP-1-treated cultures vs controls for individual glucose concentrations (Student's $t$-test). 
Bonner-Weir 2000a Islet growth and development in the adult. Fournal of Molecular Endocrinology 24 1-6.

Bonner-Weir $2001 \beta$-Cell turnover - its assessment and implications. Diabetes 50 S520-524.

Bonner-Weir S, Leahy JL \& Weir GC 1988 Induced rat models of non-insulin-dependent diabetes mellitus. In Lessons from Animal Diabetes II, pp 295-300. Eds E Shapiro \& AE Renold. London: John Libbey \& Co. Ltd.

Bonner-Weir S, Baxter LA, Schuppin GT \& Smith F 1993 A second pathway for regeneration of adult exocrine and endocrine pancreas: a possible recapitulation of embryonic development. Diabetes 2 1715-1720.

Bonner-Weir S, Taneja M, Weir GG, Tatarkiewicz K, Song KH, Sharma A \& O'Neil JJ 2000 b In vitro cultivation of human islets from expanded ductal tissue. PNAS 97 7999-8004.

Brockenbrough JS, Weir GC \& Bonner-Weir S 1988 Discordance of exocrine and endocrine growth after $90 \%$ pancreatectomy in rats. Diabetes 37 232-236.

Coffman FD \& Studzinski GP 1999 Differentiation-related mechanisms which suppress DNA replication. Experimental Cell Research 248 58-73.

Fernandes A, King LC, Guz Y, Stein R, Wright CVE \& Teitelman G 1997 Differentiation of new insulin-producing cells is induced by injury in adult pancreatic islets. Endocrinology 4 1750-1762.

Finegood DT, McArthur MD, Kojwang D, Thomas MJ, Topp BG, Leonard T \& Buckingham RE 2001 Beta-cell mass dynamics in Zucker diabetic fatty rats. Rosiglitazone prevents the rise in net cell death. Diabetes 50 1021-1029.

Gu D \& Sarvetnick N 1993 Epithelial cell proliferation and islet neogenesis in IFN- $\gamma$ transgenic mice. Development 118 33-46.

Harper JW, Elledge SJ, Keyomarsi K, Dynlact B, Tsai L-H, Zhang P, Dobrowolski S, Bai C, Connell-Crowley L, Swindell E, Fox MP \& Wei N 1995 Inhibition of cyclin-dependent kinases by p21. Molecular Biology of the Cell 6 387-400.

Hellestrom C, Andersson A \& Gunnarsson R 1996 Regeneration of islet cells. Acta Endocrinologica 83 145-158.

Hui H, Wright C \& Perfetti R 2001 GLP-1 induces differentiation of IDX-1 positive pancreatic ductal cells into insulin secreting cells. Diabetes 50 785-796.

Khaksa G, Nalini K, Bhat M \& Udupa N 1998 High-performance liquid chromatographic determination of insulin in rat and human plasma. Analytical Biochemistry $26092-95$.

Klöppel G, Lohr M, Habich K, Oberholzer M \& Heitz PU 1985 Islet pathology and the pathogenesis of type 1 and type 2 diabetes mellitus revisited. Survey and Synthesis of Pathology Research 4 $110-125$.

Magnuson MA, Andreone TL, Printz RL, Koch S \& Granner DK 1989 Rat glucokinase gene: structure and regulation by insulin. PNAS 86 4838-4842.

Nudel U, Zakut R, Shani M, Neuman S, Levy Z \& Yaffe D 1983 The nucleotide sequence of the rat cytoplasmic beta-actin gene. Nucleic Acids Research 11 1759-1771.

Pederson RA, White HA, Schlenzig D, Pauly RP, McIntosh CHS \& Demuth HU 1998 Improved glucose tolerance in Zucker fatty rats by oral administration of the dipeptidyl peptidase IV inhibitor isoleucine thiazolidide. Diabetes 47 1253-1258.

Perfetti R, Zhou J, Doyle ME \& Egan JM 2000 GLP-1 induces cell proliferation, PDX-1 expression and increases endocrine cell mass in the pancreas of old, glucose-intolerant rats. Endocrinology 141 4600-4605.

Pestell RG, Albanese C, Reutens AT, Segall JE, Lee RJ \& Arnold A 1999 The cyclins and cyclin-dependent kinase inhibitors in hormonal regulation of proliferation and differentiation. Endocrine Reviewes 20 501-534.

Pick A, Clark J, Kubstrup C, Levisetti M, Pugh W, Bonner-Weir S \& Polonsky KS 1998 Role of apoptosis in failure of beta-cell mass compensation for insulin resistance and beta-cell defects in the male Zucker diabetic fatty rat. Diabetes 47 358-364.

Polyak K, Lee M, Erdjument-Bromage H, Koff A, Tempst P, Roberts JM \& Massague J $1994 a$ Cloning of p2 $7^{\mathrm{Kip} 1}$, a cyclin-dependent kinase inhibitor and a potential mediator of extracellular antimitogenic signals. Cell 78 59-66.

Polyak K, Kato Y, Solomon MJ, Sherr CJ, Massague J, Roberts JM \& Koff A $1994 b$ p27 Kip1 , a cyclin-dependent kinase inhibitor, links transforming growth factor-b and contact inhibition to cell cycle arrest. Genes and Development 8 9-22.

Ramiya VK, Maraist M, Arfors KE, Schatz DA, Peck AE \& Conrnelius JG 2000 Reversal of insulin-dependent diabetes using islets generated in vitro from pancreatic stem cells. Nature Medicine 6 278-282.

Reed SI 1996 G1/S regulatory mechanisms from yeast to man. Progress in Cell Cycle Research 3 15-27.

Sharma A, Zangen DH, Reitz P, Taneja M, Lissauer ME, Miller GP, Weir GC, Habener JF \& Bonner-Weir S 1999 The homeodomain protein IDX-1 increases after an early burst of proliferation during pancreatic regeneration. Diabetes $\mathbf{4 8}$ 507-513.

Sherr CJ 1994 Gl phase progression: cyclin on cue. Cell 79 551-555.

Sherr CJ \& Roberts JM 1995 Inhibitors of mammalian G1 cyclin-dependent kinases. Genes and Development 9 1149-1163.

Sorenson R \& Brelje T 1997 Adaptation of islets of Langerhans to pregnancy: beta-cell growth, enhanced insulin secretion and the role of lactogenic hormones. Hormone and Metabolic Research 29 301-307.

Stoffers DA, Kieffer TJ, Hussain MA, Drucker DJ, Bonner-Weir S, Habener JF \& Egan JM 2000 Insulinotropic glucagon-like peptide 1 agonists stimulate expression of homeodomain protein IDX-1 and increase islet size in mouse pancreas. Diabetes 49 741-748.

Thorens B, Sarkar HK, Kaback HR \& Lodish HF 1988 Cloning and functional expression in bacteria of a novel glucose transporter present in liver, intestine, kidney, and beta-pancreatic islet cells. Cell $\mathbf{5 5}$ 281-290.

Toyoshima H \& Hunter T 1994 p27, a novel inhibitor of G1 cyclin-Cdk protein kinase activity, is related to p21. Cell 78 67-74.

Ullrich A, Shine J, Chirgwin J, Pictet R, Tischer E, Rutter WJ \& Goodman HM 1977 Rat insulin genes: construction of plasmids containing the coding sequences. Science 196 1313-1319.

Waguri M, Yamamoto K, Miyagawa J, Tochino Y, Yamamor K, Kajimoto Y, Nakajima H, Watada H, Yoshiuchi I, Itoh N, Imagawa A, Namba M, Kuwajima M, Yamasaki Y, Hanafusa T \& Matsuzawa Y 1997 Demonstration of two different processes of $\beta$-cell regeneration in a new diabetic mouse model induced by selective perfusion of alloxan. Diabetes 46 1281-1290.

Wang RN, Klöppel G \& Bouwens L 1995 Duct-to-islet cell differentiation and islet growth in the pancreas of duct-ligated adult rats. Diabetologia 38 1405-1411.

Wang RN, Bouwens L \& Klöppel G 1996 Beta-cell growth in adolescent and adult rats treated with streptozotocin during the neonatal period. Diabetologia 39 548-557.

Wang Y, Perfetti R, Greig NH, Holloway HW, DeOre KA, Montrose-Rafizadeh C, Elahi D \& Egan JM 1997 Glucagon-like peptide-1 can reverse the age-related decline in glucose tolerance in rats. Foumal of Clinical Investigation 99 2883-2889.

Xu G, Stoffers DA, Habener F \& Bonner-Weir S 1999 Exendin-4 stimulates both beta-cell replication and neogenesis, resulting in increased beta-cell mass and improved glucose tolerance in diabetic rats. Diabetes 48 2270-2276.

Received 12 July 2002

Accepted 17 July 2002 